\title{
Cancer risk around the nuclear power plants of Trillo and Zorita (Spain)
}

\author{
A Silva-Mato, D Viana, M I Fernández-SanMartín, J Cobos, M Viana
}

Occup Environ Med 2003;60:521-527

See end of article for authors' affiliations

Correspondence to Professor A Silva-Mato, Department of Sanitary and Socio-Medical Sciences, Area of Preventive Medicine and Public Health, Biostatistics and Epidemiology Units, University of Alcalá, Madrid 28871, Spain; agustin.silva@uah.es

Accepted 21 September 2002
Aim: To investigate the association between cancer risk and proximity of place of residence to the Guadalajara nuclear power plants: Trillo and Zorita.

Methods: Case-control study. Cases were patients admitted with cancer and controls were non-tumorous patients, both admitted to Guadalajara Hospital (period 1988-99). Exposure factor: place of residence (areas within 10,20, and $30 \mathrm{~km}$ of each plant). Odds ratios (ORs) of those areas closest to the plants were calculated with respect to those furthest away; a linear trend analysis was also performed.

Results: In the extreme areas in the vicinity of Trillo, an OR of 1.71 was obtained $(95 \% \mathrm{Cl} 1.15$ to $2.53)$, increasing in magnitude in the subgroup of more radioinducible tumours and in the period considered as post-latency (1997-99). Risk increased linearly with proximity to the two plants, significantly in Trillo $(p<0.01)$ but not in Zorita $(p=0.19)$.

Conclusions: There is an association between proximity of residence to Trillo and cancer risk, although the limitations of the study should be kept in mind when interpreting the possible causal relation.
$\mathrm{D}$ espite numerous studies of low dose exposure to ionising radiation performed by the scientific community since 1947 (the year in which the Radiation Effect Research Foundation (RERF) was created), there is still much uncertainty in the evaluation of risk, both of the doseresponse relation and of the existence and quantification of a practical dose threshold. ${ }^{1-3}$

This uncertainty, mainly of oncological risk, is especially projected onto resident populations in the areas of influence around nuclear power plants. This population may be subjected to greater radioactive exposure, as shown by biological dosimetry in the inhabitants from the area surrounding the nuclear plant in Krümmel (Germany). ${ }^{4}$

To date, there is no conclusive epidemiological evidence to support the hypothesis of greater cancer risk around these nuclear facilities. In contrast with studies that find an increased risk for leukaemia, ${ }^{5-10}$ certain specific tumours, ${ }^{11}$ and all tumours, ${ }^{13}{ }^{14}$ other studies, carried out in similar circumstances, show negative results. ${ }^{15-17}$

In Spain, where few of these types of studies have been carried out, an excessive mortality owing to leukaemia was found around uranium concentrate factories in Andujar and Ciudad Rodrigo, as well as multiple myeloma in the area influenced by the plant in Zorita (Guadalajara). ${ }^{18}$ Although in this latter study Spanish nuclear installations were studied as a whole, the Trillo plant was not studied as it started up towards the end of the study period (1975-93).

According to the reports of the "Consejo de Seguridad Nuclear" (Nuclear Safety Council), ${ }^{19}$ the only regulatory organisation in Spain for radiological protection materials, both plants (Zorita and Trillo) have experienced normal working function, in both radioactive emissions to the environment and doses received by those working at the plants. However, the need to respond to the anxiety generated by both nuclear installations in the population residing in the respective areas was the motivation for the present study, the objective of which was to determine the association between development of malignant tumours and the degree of proximity of place of residence to the nuclear power stations in the province of Guadalajara.

\section{MATERIALS AND METHODS}

The province of Guadalajara is located in the centre of Spain, to the northeast of Madrid, with a population of 156951 inhabitants ("list of inhabitants" from 1996). Spanish public health services are universal, and in Guadalajara these services are provided by 26 primary care centres and only one hospital with 370 beds to which those patients requiring hospital admittance are referred.

In the province, there are two low water pressure nuclear power stations: Zorita, which started up in 1968, and Trillo, which began operations in 1987.

The study design utilised was a case-control study. Cases were patients with cancer and controls were non-tumorous patients, both admitted to Guadalajara Hospital. Exposure factor was the place of residence (areas within 10, 20, and 30 $\mathrm{km}$ of each plant).

This paper forms part of a more extensive study where, in addition to the areas surrounding the plants, the regions that make up the province were analysed. ${ }^{20}$

The cases included were all patients with malignant tumours admitted to the Hospital de Guadalajara between 27 December 1988 and 16 January 1999. Inclusion criteria were: admittance for non-secondary malignant tumour pathology, and residence in the province. Those patients admitted more than once in the study period count as one case and the date of admittance used was that of the initial admittance. A total of 4492 cases met the inclusion criteria, of which 838 resided in the areas in the vicinity of the nuclear power stations.

Controls were chosen from patients admitted to the same hospital and during the same period of time. The controls selected were those that fulfilled the following criteria: admittance for non-tumorous pathology, no tumorous pathology indicated on the admittance report, and residence in the province. For those persons admitted more than once during the

Abbreviations: ICRP, International Commission on Radiological Protection; OR, odds ratio; RERF, Radiation Effect Research Foundation; $\mathrm{ZCl}$, zone of common influence 


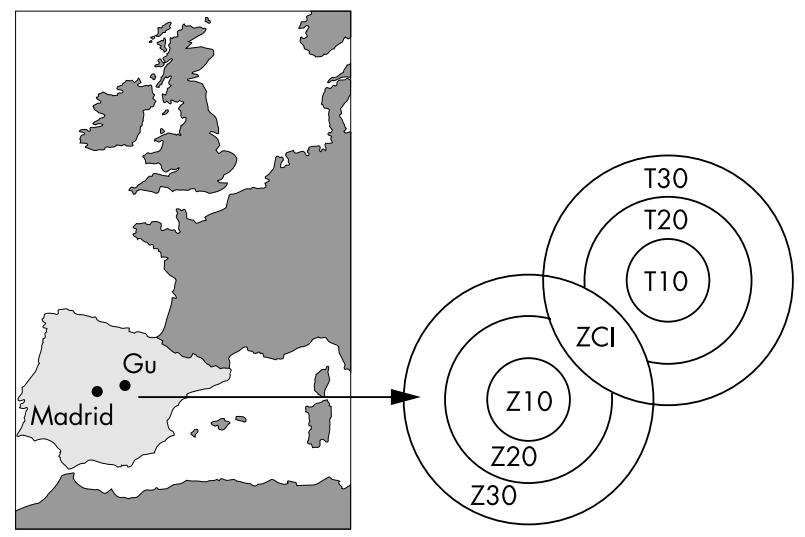

Figure 1 Zones of influence of the Trillo (T) and Zorita (Z) nuclear power plants. Gu, Guadalajara.

referred time period, we adopted the same criteria as for the clinical cases. A total of 9876 controls met these requirements throughout the province, of which 1524 resided in the areas surrounding the plants. Of these, a stratified selection was carried out by sex and age group $(<40,40-59,60-79$, and $\geqslant 80$ ). This stratification was completed for each of the analyses of the different tumour groups contemplated in this study in order for the odds ratio to be controlled for age and sex. The stratification done for each analysis led to different control subject totals in each one. As such, the total number of controls selected for the global analysis was 4377, of which 802 resided in the areas surrounding the stations, although this number varied in the rest of the analyses.

The exposure variable was the degree of proximity of place of residence to the nuclear power stations. Evaluation of this variable was performed by establishing the following zones (fig 1):

- T10, T20, and T30: Municipalities located around the Trillo plant within a radius of $0-10 \mathrm{~km}, 10-20 \mathrm{~km}$, and $20-30 \mathrm{~km}$, respectively, and not included in the zone of common influence (ZCI) with the Zorita plant.

- Z10, Z20, and Z30: As above, but for the Zorita plant.

- ZCI: Zone of common influence, influenced by both plants, which is constituted by the intersection of the $30 \mathrm{~km}$ radii.

The population living in the mentioned zones of influence, according to the "list of inhabitants" of 1996, was 27802 and the total number of municipalities was 134. According to the municipal lists of inhabitants, the population remained practically stable during the study period (fig 2). Each of the zones is rural in nature, the population density ranging between 4 and 13 inhabitants per $\mathrm{km}^{2}$ and the largest population nucleus having no more than 1800 inhabitants.

The information source used for pathology as well as for place of residence is the computerised database of discharge reports from hospital, completed for each patient admitted, provided by the Admission and Clinical Documentation Services of the hospital. Clinical histories were discarded as sources of information because, after a systematic review of 265 histories, we noted an absence of data on confounding factors in $30 \%$ of these.

As we were unable to evaluate the smoking habits of each subject because this information was not present in the clinical histories, this was evaluated indirectly as a possible confounding factor. To do so, we quantified among the controls and in each zone surrounding the power stations, the number of persons affected by pathologies related to smoking, as well as that of persons affected by pathologies not related to it, comparing both distributions. The following pathologies that are strongly related to smoking were considered: ischaemic heart disease, chronic obstructive pulmonary disease, cer-
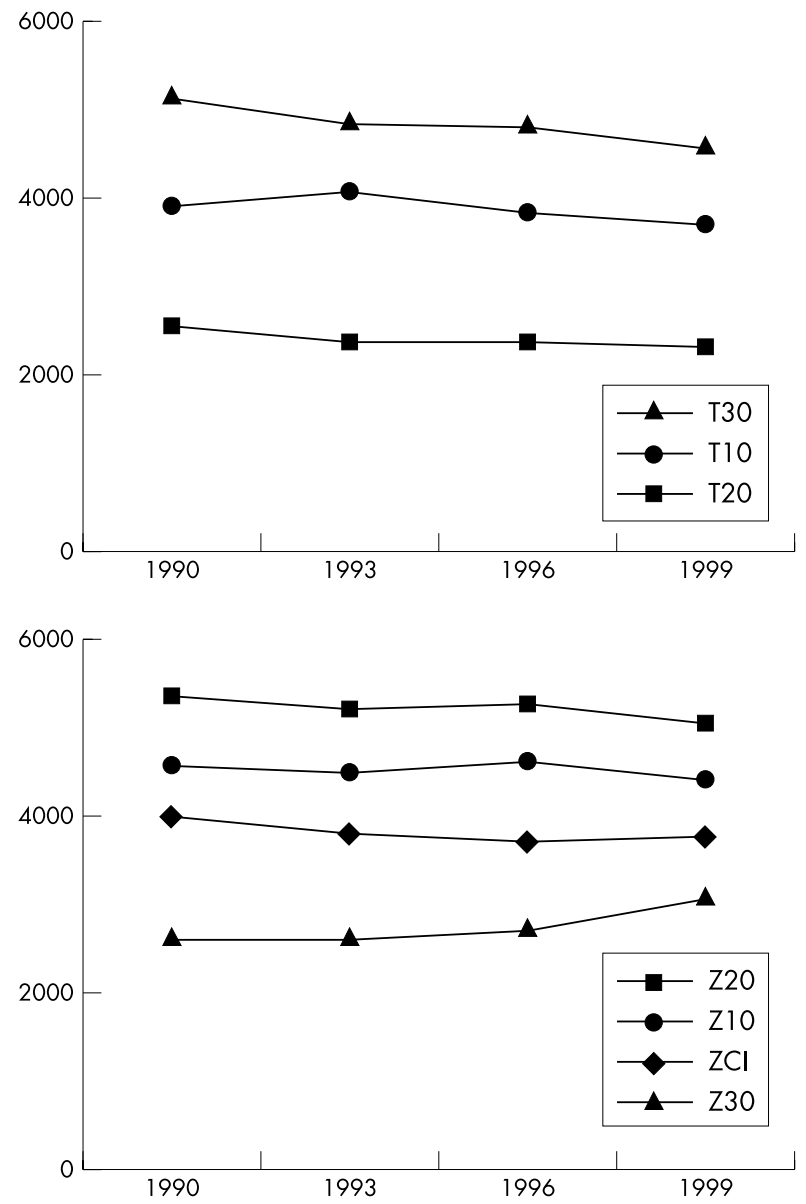

Figure 2 Evolution of the population (number of inhabitants per year) residing in the zones surrounding the Trillo (T) and Zorita $(Z)$ nuclear power stations.

ebrovascular accident, arterial embolism and thrombosis, chronic laryngitis, and pharyngitis. ${ }^{21}$

Others variables were:

- Radioinducibility of the tumours: Two categories were defined (tumours that are less or not at all radioinducible and the remainder of the tumours grouped in the category of more radioinducible tumours). Considered as less radioinducible are those tumours whose association with radiation is not significant as outlined in Report 12 of the RERF $^{22}$ (foundation that researches the mortality of survivors of atomic bombs) and, in addition, have not been referred to with a positive association in the overall bibliographic review. Tumours considered as less radioinducible are: rectal and anal, pancreatic, laryngeal, uterine, renal, non-Hodgkin's lymphoma, Hodgkin's disease, and chronic lymphatic leukaemia.

- Period of latency: The minimal time interval estimated by the International Commission on Radiological Protection $(\text { ICRP })^{23}$ between exposure to radiation and appearance of the tumour is two years for leukaemia and five for other tumours, although after the Chernobyl accident, ${ }^{24}$ and as a result of radon studies in miners, ${ }^{25}$ somewhat shorter latency periods have been found. In the study of the area surrounding Trillo, given that this plant started up one year before our study began and in order to take into consideration the latency period, we analysed the periods 1989-93, 1994-96, and 1997-99, considering only the latter to be outside the latency period. Nevertheless, as the Zorita plant began its operations in 1968, it was not necessary to consider latency period in the study of its surrounding area. 
Table 1 Cases and controls adjusted for age and sex for all tumours during the entire period studied

\begin{tabular}{|c|c|c|c|c|}
\hline \multirow[b]{2}{*}{ Zones } & \multicolumn{2}{|c|}{ Cases } & \multicolumn{2}{|c|}{ Controls } \\
\hline & No. & $\%$ & No. & $\%$ \\
\hline T30 & 141 & 16.83 & 164 & 20.45 \\
\hline T20 & 70 & 8.35 & 69 & 8.59 \\
\hline T10 & 88 & 10.50 & 60 & 7.48 \\
\hline $\mathrm{Z} 30$ & 102 & 12.17 & 112 & 13.97 \\
\hline $\mathrm{Z} 20$ & 161 & 19.21 & 160 & 19.95 \\
\hline Z10 & 144 & 17.18 & 125 & 15.59 \\
\hline $\mathrm{ZCl}$ & 132 & 15.75 & 112 & 13.97 \\
\hline Total & 838 & 100 & 802 & 100 \\
\hline \multicolumn{5}{|l|}{ Age } \\
\hline$<40$ & 25 & 3.0 & 23 & 2.9 \\
\hline $40-59$ & 103 & 12.3 & 99 & 12.3 \\
\hline $60-79$ & 539 & 64.3 & 511 & 63.7 \\
\hline$\geqslant 80$ & 171 & 20.4 & 169 & 21.1 \\
\hline \multicolumn{5}{|l|}{ Sex } \\
\hline Females & 304 & 36.3 & 284 & 35.4 \\
\hline Males & 534 & 63.7 & 518 & 64.6 \\
\hline
\end{tabular}

The following analyses were performed:

- Calculation of odds ratio (OR) for all tumuors, and for tumour groups that are more and less radioinducible for the areas that are closest to the plants, T10 and Z10, with respect to those that are furthest (areas within radii 20, 30, and $\mathrm{ZCI}$ ). The $95 \%$ confidence interval (CI) was calculated. ${ }^{26} 27$

- Calculation of previous OR for each of the three periods studied in the area surrounding Trillo, 1989-93, 1994-96, and 1997-99.

- Linear trend analysis ${ }^{26}$ of the previous OR with respect to degree of distance from the nuclear plants, using the $\chi^{2}$ test. The ZCI area was not included in this analysis as it is not an area comparable with the rest regarding distance slope.

- Calculation of homogeneity for pathologies related to tobacco and geographical zone of residence for controls, using the $\chi^{2}$ test.

\section{RESULTS}

Table 1 shows the total number of cases in each zone studied, as well as selected controls adjusted for age and sex. Table 2 shows the pathologies of the control group according to the large groupings of the CIE 9. In the vicinity of the Trillo plant, 299 cases and 293 controls lived; in the vicinity of the Zorita plant, 407 cases and 397 controls lived. In the intersecting zone, ZCI, 132 cases and 112 controls lived.

Calculation of the OR for malignant tumour risk was performed according to the degree of proximity to the nuclear power plants (table 3). As can be observed, the OR between $\mathrm{T} 10$ and T30 was statistically significant $(\mathrm{p}=0.01)$. Thus, it is estimated that persons living in municipalities located less than $10 \mathrm{~km}$ from the Trillo plant have a risk of developing a malignant tumour 1.71 times greater than those living in municipalities located at a distance of between 20 and $30 \mathrm{~km}$ from the plant.

The differences were not significant in the rest of the comparisons, but a progressive decrease in OR was observed in both plants. By means of the linear trend test, the statistical significance of this tendency was verified for the area surrounding Trillo $(\mathrm{p}=0.009)$, but not for the areas around Zorita $(\mathrm{p}=0.196)$.

There were 163 cases of less radioinducible tumours, and 675 of those considered more radioinducible. Table 4 shows

Table 2 Pathologies of the control group according to the large groupings of the CIE 9

\begin{tabular}{ll}
\hline CIE 9 group & Most frequent pathologies \\
\hline I. Infectious & Septicaemia, other infections by Salmonella, echinococcosis \\
III. Endocrine & Non-toxic nodular goitre, diabetes \\
IV. Blood & Phenopenic anaemias, haemorrhagic affectations \\
V. Mental disorders & Affective and schizophrenic psychosis \\
VI. Nervous system and sensory organs & Cataracts, glaucoma, conjunctival disorders, mononeuritis \\
VII. Circulatory & Acute myocardial infarction, angina, hypertension, cardiac insufficiency, \\
& cardiomyopathy, arrhythmia, cerebrovascular accident, varicose veins, haemorrhoids \\
VIII. Respiratory & Pneumonia, chronic bronchitis, severe bronchitis, nasal polyps \\
IX. Digestive & Acute appendicitis, hernias of the abdominal cavity, ulcers, intestinal obstruction, \\
& diverticulitis, cholelithiasis, anal fissures and fistulas \\
X. Genitourinary & Hyperplasia of the prostate, hydrocele, genital prolapse, menopausal and menstrual \\
& disorders \\
XI. Complications of pregnancy & Spontaneous miscarriage, retained miscarriage \\
XII. Skin and subcutaneous tissue & Pilonidal cyst, dermatitis \\
XIII. Osteomuscular and conjunctival & Osteoarthritis, internal knee anomalies, malformations of the appendages \\
XIV. Congenital anomalies & Osteomuscular anomalies \\
XVI. Undefined morbid states & Symptoms related to the neck and head \\
XVII. Traumatisms & Femur neck fracture, ankle fracture, tibia fracture \\
& Total \\
\hline
\end{tabular}




\begin{tabular}{|c|c|c|c|c|c|}
\hline & Cases & Controls & OR & $95 \% \mathrm{Cl}$ & $p$ value \\
\hline $\begin{array}{l}\text { T10 } \\
\text { T30 }\end{array}$ & $\begin{array}{r}88 \\
141\end{array}$ & $\begin{array}{r}60 \\
164\end{array}$ & 1.71 & 1.15 to 2.53 & 0.01 \\
\hline $\begin{array}{l}\text { T10 } \\
\text { T20 }\end{array}$ & $\begin{array}{l}88 \\
70\end{array}$ & $\begin{array}{l}60 \\
69\end{array}$ & 1.45 & 0.91 to 2.30 & 0.15 \\
\hline $\begin{array}{l}\mathrm{T} 10 \\
\mathrm{ZCl}\end{array}$ & $\begin{array}{r}88 \\
132\end{array}$ & $\begin{array}{r}60 \\
112\end{array}$ & 1.24 & 0.82 to 1.88 & 0.35 \\
\hline $\begin{array}{l}\mathrm{Z} 10 \\
\mathrm{Z} 30\end{array}$ & $\begin{array}{l}144 \\
102\end{array}$ & $\begin{array}{l}125 \\
112\end{array}$ & 1.27 & 0.88 to 1.81 & 0.23 \\
\hline $\begin{array}{l}\text { Z10 } \\
\text { Z20 }\end{array}$ & $\begin{array}{l}144 \\
161\end{array}$ & $\begin{array}{l}125 \\
160\end{array}$ & 1.15 & 0.83 to 1.58 & 0.46 \\
\hline $\begin{array}{l}\mathrm{Z} 10 \\
\mathrm{ZCl}\end{array}$ & $\begin{array}{l}144 \\
132\end{array}$ & $\begin{array}{l}125 \\
112\end{array}$ & 0.98 & 0.69 to 1.38 & 0.96 \\
\hline
\end{tabular}

the distribution of tumours by organs and according to the degree of radioinducibility.

In the area surrounding Trillo, the risk of having a tumour classified in the more radioinducible group was greater among those living in zone T10 than for those in zone T30 (OR 1.86; 95\% CI 1.22 to 2.83). As before, the linear trend test showed significance $(p=0.04)$ for the progressive decrease in OR (table 5). This association was not maintained for the comparison of the same zones with respect to the less radioinducible tumour group (OR 1.08; $\mathrm{p}=0.97$ ). In the area surrounding Zorita, the association was not significant in either of the two tumour groups.

If the excess risk observed in Trillo were due to the plant, given the period of latency the excess would manifest itself in the later years of our study period. The results for the three time periods contemplated (table 6) indicated no relation between the degree of proximity of place of residence and development of a malignant tumour in the first time period as well as in the second-that is, between 1989 and 1996. This changed in the last period, between 1997 and 1999, in which we found a greater risk of having tumours in general, and specifically more radioinducible tumours, if living in zone T10 when compared with other zones around the area. The decreasing linear trend for risk was significant in the group of all tumours as well as in the more radioinducible group $(\mathrm{p}=0.002)$. The less radioinducible tumours showed insignificant ORs in all periods.

\begin{tabular}{|c|c|c|}
\hline Tumours & Code & Total \\
\hline \multicolumn{3}{|l|}{ Less radioinducible } \\
\hline Rectum & 154 & 52 \\
\hline Pancreas & 157 & 17 \\
\hline Larynx & 161 & 23 \\
\hline Kidney & 189 & 20 \\
\hline Uterus & $179,180,182$ & 17 \\
\hline Hodgkin's & 201 & 6 \\
\hline Lymphomas & 202 & 18 \\
\hline $\mathrm{CL}$ & 204.1 & 10 \\
\hline Total less radioinducible & & 163 \\
\hline \multicolumn{3}{|l|}{ More radioinducible } \\
\hline Stomach & 151 & 74 \\
\hline Colon & 153 & 71 \\
\hline Liver and vesicle & 155 & 41 \\
\hline Lung & 162 & 103 \\
\hline Ovary & 183 & 22 \\
\hline Prostate & 185 & 74 \\
\hline Bladder & 188 & 83 \\
\hline Encephalon & 191 & 8 \\
\hline Thyroid & 193 & 4 \\
\hline Myeloma & 203 & 10 \\
\hline Skin & 172,173 & 39 \\
\hline Breast & 174 & 74 \\
\hline Leukaemia other than CLL & $204.0,205$ & 21 \\
\hline Mouth and pharynx & 140,149 & 15 \\
\hline Oesophagus & 150 & 5 \\
\hline Bone and conjuntiva & 170 & 7 \\
\hline Other & $184,189,190,199163$ & 24 \\
\hline Total more radioinducible & & 675 \\
\hline
\end{tabular}

CLL, chronic lymphocytic leukaemia. 


\begin{tabular}{|c|c|c|c|c|c|c|c|c|c|c|}
\hline \multirow{2}{*}{$\begin{array}{l}\text { Areas } \\
\text { compared }\end{array}$} & \multicolumn{5}{|c|}{ More radioinducible tumours } & \multicolumn{5}{|c|}{ Less radioinducible tumours } \\
\hline & Cases & Controls & OR & $95 \% \mathrm{Cl}$ & $p$ value & Cases & Controls & OR & $95 \% \mathrm{Cl}$ & $p$ value \\
\hline $\begin{array}{l}\text { T10 } \\
\text { T30 }\end{array}$ & $\begin{array}{r}75 \\
109\end{array}$ & $\begin{array}{r}56 \\
151\end{array}$ & 1.86 & 1.22 to 2.83 & 0.006 & $\begin{array}{l}13 \\
32\end{array}$ & $\begin{array}{r}68 \\
182\end{array}$ & 1.08 & 0.53 to 2.21 & 0.97 \\
\hline $\begin{array}{l}\text { T10 } \\
\text { T20 }\end{array}$ & $\begin{array}{l}75 \\
57\end{array}$ & $\begin{array}{l}56 \\
64\end{array}$ & 1.50 & 0.92 to 2.47 & 0.14 & $\begin{array}{l}13 \\
13\end{array}$ & $\begin{array}{l}68 \\
76\end{array}$ & 1.12 & 0.48 to 2.58 & 0.96 \\
\hline $\begin{array}{l}\mathrm{T} 10 \\
\mathrm{ZCl}\end{array}$ & $\begin{array}{l}75 \\
99\end{array}$ & $\begin{array}{r}56 \\
103\end{array}$ & 1.39 & 0.90 to 2.16 & 0.17 & $\begin{array}{l}13 \\
33\end{array}$ & $\begin{array}{r}68 \\
127\end{array}$ & 0.74 & 0.37 to 1.45 & 0.50 \\
\hline $\begin{array}{l}\text { Z10 } \\
\text { Z30 }\end{array}$ & $\begin{array}{r}117 \\
88\end{array}$ & $\begin{array}{l}115 \\
102\end{array}$ & 1.17 & 0.80 to 1.73 & 0.45 & $\begin{array}{l}27 \\
14\end{array}$ & $\begin{array}{l}138 \\
129\end{array}$ & 1.79 & 0.93 to 3.46 & 0.13 \\
\hline $\begin{array}{l}\text { Z10 } \\
\text { Z20 }\end{array}$ & $\begin{array}{l}117 \\
130\end{array}$ & $\begin{array}{l}115 \\
147\end{array}$ & 1.15 & 0.81 to 1.63 & 0.48 & $\begin{array}{l}27 \\
31\end{array}$ & $\begin{array}{l}138 \\
179\end{array}$ & 1.12 & 0.64 to 1.99 & 0.79 \\
\hline $\begin{array}{l}\mathrm{Z} 10 \\
\mathrm{ZCl}\end{array}$ & $\begin{array}{r}117 \\
99\end{array}$ & $\begin{array}{l}115 \\
103\end{array}$ & 1.06 & 0.73 to 1.54 & 0.84 & $\begin{array}{l}27 \\
33\end{array}$ & $\begin{array}{l}138 \\
127\end{array}$ & 0.74 & 0.43 to 1.32 & 0.38 \\
\hline
\end{tabular}

Among the controls, the total number of patients with pathologies related to smoking in the province was 1239, of which 222 lived in the areas around the nuclear plants. A total of 1982 controls were affected by pathologies unrelated to smoking, of which 354 lived in the areas around the plants. The $\chi^{2}$ resulting from the comparison of the distributions of

\begin{tabular}{|c|c|c|c|c|}
\hline & Т10-Т30 & T10-T20 & $\mathrm{T} 10-\mathrm{ZCI}$ & T10-Rest of Trillo \\
\hline \multicolumn{5}{|c|}{ Period 1 (1989-93) } \\
\hline \multicolumn{5}{|c|}{ More radioinducible tumours } \\
\hline Cases & $28-49$ & $28-21$ & $28-49$ & $28-119$ \\
\hline Controls & $23-60$ & $23-19$ & $23-39$ & $23-118$ \\
\hline OR & 1.49 & 1.10 & 0.96 & 1.21 \\
\hline $95 \% \mathrm{Cl}$ & 0.72 to 3.07 & 0.44 to 2.75 & 0.46 to 2.06 & 0.66 to 2.21 \\
\hline$p$ value & 0.31 & 0.98 & 0.99 & 0.65 \\
\hline \multicolumn{5}{|c|}{ Less radioinducible tumours } \\
\hline Cases & $8-13$ & $8-8$ & $8-22$ & $8-43$ \\
\hline Controls & $23-56$ & $23-19$ & $23-38$ & $23-113$ \\
\hline OR & 1.50 & 0.83 & 0.60 & 0.91 \\
\hline $95 \% \mathrm{Cl}$ & 0.53 to 4.24 & 0.26 to 2.62 & 0.24 to 1.51 & 0.38 to 2.17 \\
\hline p value & 0.60 & 0.98 & 0.42 & 0.99 \\
\hline \multicolumn{5}{|c|}{ Period 2 (1994-96) } \\
\hline \multicolumn{5}{|c|}{ More radioinducible tumours } \\
\hline Cases & $22-37$ & $22-18$ & $22-26$ & $22-81$ \\
\hline Controls & $23-53$ & $23-20$ & $23-34$ & $23-107$ \\
\hline OR & 1.37 & 1.06 & 1.25 & 1.26 \\
\hline $95 \% \mathrm{Cl}$ & 0.67 to 2.82 & 0.45 to 2.52 & 0.58 to 2.72 & 0.66 to 2.43 \\
\hline$p$ value & 0.50 & 0.99 & 0.71 & 0.29 \\
\hline \multicolumn{5}{|c|}{ Less radioinducible tumours } \\
\hline Cases & $4-13$ & $4-3$ & $4-2$ & $4-18$ \\
\hline Controls & $33-75$ & $33-31$ & $33-51$ & $33-157$ \\
\hline OR & 0.70 & 1.25 & 3.09 & 1.06 \\
\hline $95 \% \mathrm{Cl}$ & 0.23 to 2.14 & 0.26 to 5.97 & 0.57 to 16.64 & 0.56 to 5.74 \\
\hline$p$ value & 0.76 & 0.99 & 0.79 & 0.99 \\
\hline \multicolumn{5}{|c|}{ Period 3 (1997-99) } \\
\hline \multicolumn{5}{|c|}{ More radioinducible tumours } \\
\hline Cases & $25-23$ & $25-18$ & $25-24$ & $25-65$ \\
\hline Controls & $8-34$ & $8-21$ & $8-27$ & $8-82$ \\
\hline OR & 4.61 & 3.65 & 3.52 & 3.94 \\
\hline $95 \% \mathrm{Cl}$ & 1.96 to 10.90 & 1.42 to 9.38 & 1.96 to 8.55 & 1.85 to 8.38 \\
\hline$p$ value & 0.003 & 0.021 & 0.017 & 0.002 \\
\hline \multicolumn{5}{|c|}{ Less radioinducible tumours } \\
\hline Cases & $1-6$ & $1-2$ & $1-9$ & $1-17$ \\
\hline Controls & $10-42$ & $10-24$ & $10-34$ & $10-100$ \\
\hline OR & 0.70 & 1.20 & .38 & 0.59 \\
\hline $95 \% \mathrm{Cl}$ & 0.09 to 5.31 & 0.09 to 15.88 & 0.07 to 2.08 & 0.10 to 3.48 \\
\hline$p$ value & 0.99 & 0.99 & 0.64 & 0.97 \\
\hline
\end{tabular}


the two pathology groups among the different zones surrounding the power stations is $3.69(\mathrm{df}=6)$, with a statistical significance of 0.72 . Therefore, the zones are homogeneous with respect to the incidence of pathologies related to smoking, and as such there is no reason to suspect that smoking can explain the differences in risk found.

\section{DISCUSSION}

The influence of proximity of place of residence to a nuclear power station on risk for malignant tumours is suggested by our study in the case of Trillo for the following reasons:

- The statistical association is positive, although small, when the area within a $10 \mathrm{~km}$ radius around the Trillo nuclear power plant (T10) is compared with the area found within the 20 and $30 \mathrm{~km}$ radii around the plant (T30).

- This association occurs in the "all tumours" group and in the more radioinducible group, where an increased magnitude is also seen.

- The association only occurs in the third period contemplated - that is, between 9 and 11 years after the plant started up, when the magnitude also increased. This interval would already be outside the latency period according to the criteria of the ICRP. ${ }^{23}$

- The linear trend shows a dose-response relation: as exposure diminishes (as place of residence is further removed from the plants), so does risk of having malignant tumours diminish.

Such an association between tumour risk and distance of residence from nuclear facilities was also observed by Gulis and Fitz $^{12}$ at the Jasloské Bohunice (Slovakia) nuclear plant and by Bithell and colleagues ${ }^{6}$ at the Sellafield plant.

In the area surrounding Zorita, although a decreasing tendency in risk is observed as distance from the plant increases, no significance was shown. In this case, the behaviour of the group of less radioinducible tumours $(\mathrm{p}=0.13$ in the $\mathrm{Z10}-\mathrm{Z} 30$ comparison) could be considered as an index of significance, possibly questioning the hypothesis of the influence of proximity to the power station on risk

However, in a study of mortality and organ specific tumours, López-Abente and colleagues ${ }^{18}$ did find a greater risk of mortality by myeloma in the vicinity of Zorita, also with a decreasing tendency as distance from the plant increased. We believe that the differences between the findings of both studies could be due to the fact that the study periods were quite far apart in time (14 years), during which time it is probable that the system of operations of the nuclear power station varied, and also that we included cases diagnosed whereas López-Abente et al studied mortality. In any event, the observation period of López-Abente et al (1975-93), given the start up date of Trillo (1987) and the latency period of tumours, did not allow for this plant to be studied in depth.

The description of the risk slope as a function of the distance to the power plant was done by comparing the two most proximal zones (T10 and Z10) with the remainder. Generally, the closest areas are usually compared with those farthest away, with predictably lower risks. What we saw to be a disadvantage in this scheme is that it does not compare either T10 with T20 or Z10 with Z20, which prevents us from knowing whether the zone considered to be at a predictably greater risk ( $\mathrm{T} 10$ or $\mathrm{Z10}$ ) is similar or not to the neighbouring zone. Nor does the comparison allow for a global comparison between Tl0 and the rest of the Trillo area considered as one single zone. However, the conclusions derived from the analyses following either one scheme or the other are similar, as the comparisons with T30 and Z30, not done in our study, but whose ORs can be found as coefficients of the ORs of the comparisons done previously, are not significant.

Our study displays certain limitations that should be kept in mind when interpreting the results. As nuclear installations are usually located in areas with low population density, as in the epidemiological studies reviewed, the number of cases is reduced. Having few cases and controls in each category has impeded the study of the behaviour of organ specific tumours.

Possible changes in residence prior to diagnosis are unknown. However, given the stability of the population during the study period, there is no apparent reason to suspect that this factor would have an appreciable influence. Other possible confounding factors, such as occupation and eating habits, have not been studied.

The dose-response relation obtained in the epidemiological study was not observable with the physical dosimetry available ${ }^{19}$ although the dosimetry, which includes the natural radioactive background, does not include the internal dose received by inhalation or ingestion of artificial isotopes in the different zones of the area around the nuclear plants contemplated in this study. This is an aspect which has not really been considered in earlier manuscripts ${ }^{28}$; thus it would be interesting to carry out an alternative study using biological dosimetry as was done in the area surrounding the Krümmel nuclear plant. ${ }^{4}$

In any event, the association found in the Trillo nuclear power plant could be due to the exposure suffered at the initial start up of the plant, and given that our study only includes a few years of post-latency, it would be convenient to prolong the study period in future research, at the same time trying to mitigate the effects of the limitations mentioned.

\section{ACKNOWLEDGEMENTS}

This research was supported by the University of Alcalá, grant number E017/97.

\section{Authors' affiliation}

A Silva-Mato, D Viana, M I Fernández-SanMartín, M Viana, Department of Sanitary and Socio-Medical Sciences, Area of Preventive Medicine and Public Health, Biostatistics and Epidemiology Units, University of Alcalá, Madrid, Spain

J Cobos, Guadalajara University Hospital, Guadalajara, Spain

\section{REFERENCES}

1 Hoel DG, Li P. Threshold models in radiation carcinogenesis. Health Phys 1998;75:241-50.

2 Mossman KL. The linear no-threshold debate: where do we go from here? Med Phys 1998;25:279-84.

3 Little MP, Muirhead CR. Curvature in the cancer mortality dose response in Japanese atomic bomb survivors: absence of evidence of threshold. In J Radiat Biol 1998;74:471-80.

4 Schmitz-Feuerhake II, Dannheim B, Heimers A, et al. Leukemia in the proximity of a German boiling-water nuclear reactor: evidence of population exposure by chromosome studies and environmental radioactivity. Environ Health Perspect 1997; 105:1499-504.

5 Cook-Mozaffari PJ, Darby SC, Doll R, et al. Geographical variation in mortality from leukaemia and other cancers in England and Wales in relation to proximity to nuclear installations, 1969-78. Br J Cancer 1989;59:476-85.

6 Bithell JF, Dutton SJ, Draper GJ, et al. Distribution of childhood leukaemias and non-Hodgkin's lymphomas near nuclear installations in England and Wales. BMU 1994;309:501-5.

7 Black RJ, Sharp L, Harkness EF, et al. Leukaemia and non-Hodgkin's lymphoma: incidence in children and young adults residents in the Dounreay area of Caithness, Scotland in 1968-91. J Epidemiol Community Health 1994;48:232-6.

8 Lackland D. Leukaemia in the vicinity of two tritium releasing nuclear facilities. In: Proceedings of the conference organised by the British Nuclear Energy Society, London, May 1997

9 Pobel D, Viel JF. Case-control study of leukaemia among young people near La Hague nuclear reprocessing plant: the environmental hypothesis revisited. BM 1997:314:101-6.

10 Morris MS, Knorr RS. Adult leukemia and proximity-based surrogates for exposure to Pilgrim plant's nuclear emissions. Arch Environ Health 1996;51:266-74

11 Sharp L, McKinney PA, Black RJ. Incidence of childhood brain and other non- haematopoietic neoplasms near nuclear sites in Scotland, 1975-94. Occup Environ Med 1999;56:308-14

12 Gulis G, Fitz O. Cancer incidence around the Nuclear Power Plant Jaslovske Bohunice. Cent Eur J Public Health 1998;6:183-7.

13 Draper GJ, Stiller CA, Cartwright RA, et al. Cancer in Cumbria and in the vicinity of the Sellafield nuclear installation, 1963-90. BM 1993;306:89-94. 
14 Mangano JJ. Cancer mortality near Oak Ridge, Tennessee. Int J Health Serv 1994;24:521-33.

15 Sharp L, Black RI, Harkness EF, et al. Incidence of childhood leukaemia and non-Hodgkin's lymphoma in the vicinity of nuclear sites in Scotland 1968-93. Occup Environ Med 1996:53:823-31.

16 Hattchouel JM, Laplanche A, Hill C. Cancer mortality around French nuclear sites. Ann Epidemiol 1996;6:126-9.

17 Kaatsch P, Kaletsch U, Meinert R, et al. An extended study on childhood malignancies in the vicinity of German nuclear power plants. Cancer Causes Control 1998:9:529-33.

18 López-Abente G, Aragonés N, Pollán $M$, et al. Leukemia, lymphomas, and myeloma mortality in the vicinity of nuclear power plants and nuclear fuel facilities in Spain. Cancer Epidemiol Biomark Prev 1999;8:925-34.

19 Consejo de Seguridad Nuclear. Informes al Congreso de los Diputados y al Senado 1988-1998. Madrid: CSN, 1998.

20 Viana D. Estudio epidemiológico de la asociación entre patología oncológica y grado de proximidad residencial a las centrales nucleares de la provincia de Guadalajara. Doctoral thesis. Madrid: Universidad de Alcalá, 2000.
21 Battestini R. Efectos nocivos causados por la contaminación. In: Farreras P, ed. Medicina interna, 13th edn. Madrid: Mosbby-Doyma, 1995.

22 Pierce DA, Shimizu Y, Preston DL, et al. Studies of the mortality of atomic bomb survivors. Report 12, Part I. Cancer: 1950-1990. Radiat Res 1996;146:1-27.

23 ICRP. Publication 60. Recommendations of the International Commission on Radiological Protection. Annals of the ICRP, 21 No. 1-3, 1991.

24 Ivanov VK, Rastopchin EM, Gorsky Al, et al. Cancer incidence among liquidators of the Chernobyl accident: solid tumors, 1986-1995. Health Phys 1998;74:309-15.

25 Kusiak RA, Ritchie AC, Muller J, et al. Mortality from lung cancer in Ontario uranium miners. Br J Ind Med 1993;50:920-8.

26 Breslow EN, Day EN. Statistical methods in cancer research. Vol. I: The analysis of case-control studies. Lyon: International Agency for Research on Cancer, 1980.

27 Schlesselman JJ. Case-control studies. New York: Oxford University Press, 1982.

28 Shleien B, Ruttenber AJ, Sage M. Epidemiologic studies of cancer in populations near nuclear facilities. Health Phys 1991;61:699-713.

Job grade predicts risk of cardiovascular disease in British civil servants long term

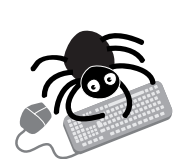

Please visit the Occupational and

Environmental Medicine website [www occenvmed.com for link to this full article prospective study of over 6500 British civil servants- the Whitehall II study-has dis-
closed that ill health and cardiovascular risk are as influenced by socioeconomic
gradient as they were over a decade ago. The change in gradient of employment grades between baseline and 11.1 years' follow up for cardiovascular illness and risk factors between the highest and lowest grades was more or less similar for most of the measures. Significantly steeper gradients were seen for General Household Questionnaire score and caseness and depression in men and women and for serum cholesterol concentration in men.

Data were used from three phases of the Whitehall II study. Phase 1 (1985-8) included screening data on height, weight, blood pressure, and serum cholesterol concentration, plus self reported questionnaire data on demographic factors, work, employment grade, lifestyle. Phases 3 (1992-3) and 5 (1997-9) contributed repeat screening data and follow up questionnaire data at 5.3 years and 11.1 years, respectively. Complete data were obtained for 6770 subjects. The significance of the change in employment grade gradient was determined from the difference in regression coefficients for the gradient at the three phases tested against the null hypothesis.

The Whitehall II study was intended to clarify the link between employment grade and mortality noted in the Whitehall I study. Population data have generally indicated that socioeconomic gradient in mortality has increased. Cardiovascular studies suggested that socioeconomic differences were stable or dropping. However, they did not address trends in cardiovascular health and risk, as the Whitehall II study has.

\ Journal of Epidemiology and Community Health 2002;56:922-926. 